\title{
GAS-PHASE ION CHEMISTRY OF SILYL CATIONS OBTAINED FROM HEXAMETHYLDISILAZANE "
}

\author{
Luciano A. Xavier, Sofia Ambra ${ }^{\dagger}$ and José M. Riveros* \\ Instituto de Química, Universidade de São Paulo, CP 26077, 05513-970 São Paulo - SP
}

Recebido em 26/3/02; aceito em 1/7/02

\begin{abstract}
GAS-PHASE ION CHEMISTRY OF SILYL CATIONS OBTAINED FROM HEXAMETHYLDISILAZANE. The gas-phase ionmolecule reactions of the $\mathrm{Me}_{3} \mathrm{SiN}(\mathrm{H}) \mathrm{SiMe}_{2}{ }^{+}$ion, obtained by electron ionization from $\mathrm{Me}_{3} \mathrm{SiN}(\mathrm{H}) \mathrm{SiMe}_{3}$, have been studied in a Fourier transform ion cyclotron resonance spectrometer in order to understand the mechanistic details of an important chemical system presently used in film formation. This silyl cation has been observed to undergo addition reactions at electron rich centers to form stable adducts that may undergo further methane elimination in the case of alcohols and amines. The most important feature of these reactions is the fact that a metathesis type reaction can be observed in the presence of $\mathrm{H}_{2} \mathrm{O}$, and other hydrogen labile substrates like alcohols, leading to the formation of the corresponding oxygen-containing ion, i.e. $\mathrm{Me}_{3} \mathrm{SiOSiMe}_{2}{ }_{2}$. For alcohols $(\mathrm{ROH})$, facile formation of a tertiary product ion, presumably corresponding to an $\mathrm{Me}_{3} \mathrm{Si}-\mathrm{O}-\mathrm{Si}(\mathrm{Me})=\mathrm{O}^{+}-\mathrm{R}$ structure with elimination of an amine reveals the strong tendency of these nitrogen-containing ions to undergo metathesis type reactions with oxygen containing substrates.
\end{abstract}

Keywords: hexamethyldisilazane; gas phase ion chemistry; silyl cation addition.

\section{INTRODUCTION}

Hexamethyldisilazane, $\left[\left(\mathrm{Me}_{3} \mathrm{Si}\right)_{2} \mathrm{NH}\right]$, commonly referred to as HMDS or HMDSN, is known to be a cheap and convenient reagent for the trimethylsilylation of hydrogen-labile substrates, i.e. alcohols, in the presence of a suitable catalyst ${ }^{1-6}$. HMDS also finds important applications in material sciences and has become the reagent of choice in plasma enhanced chemical vapor deposition (PECVD) processes aimed at the preparation of potentially interesting $\mathrm{Si}, \mathrm{N}, \mathrm{C}, \mathrm{O}-$ containing thin films $\mathrm{s}^{7-11}$. As in most plasma processes the actual chemical mechanism responsible for film formation is not fully understood although it presumably involves a mixture of neutralsurface reactions as well as gas-phase ion-molecule reactions. While reactions of gaseous HMDS on silica and alumina surfaces have been the subject of careful investigations ${ }^{12-14}$, little is known about the possible contribution of gas-phase ionic processes.

In recent years, the gas-phase positive and negative ion chemistry of substrates such as $\mathrm{Si}(\mathrm{OR})_{4}$ and $\mathrm{Ge}(\mathrm{OR})_{4}$, commonly used in the preparation of new materials by chemical vapor deposition processes or by sol-gel techniques, have been explored primarily in our laboratories ${ }^{15-19}$. The underlying motivation for these studies has been the need to characterize the elementary reactions that make these substrates unique in their applications. In the present report, we have extended our studies to the main fragment ion obtained by electron ionization of $\left(\mathrm{Me}_{3} \mathrm{Si}\right)_{2} \mathrm{NH}$ in an attempt to understand the mechanistic details associated with ionic moieties displaying $\mathrm{Si}-\mathrm{N}$ bonds. The reported chemistry yields some relevant insight on the chemistry of silyl cations, a timely matter because of the increasing interest in the reactivity and thermodynamic stability of these species ${ }^{20-22}$.

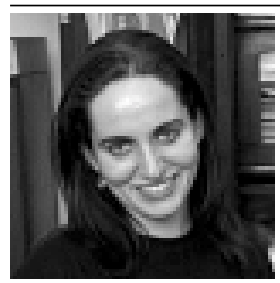

This paper is in memoriam of Sofia Ambra whose youthful energy and enthusiasm will always be remembered by this group.

Sofia Ambra (17/7/79 - 3/7/00)

\section{EXPERIMENTAL}

Gas-phase ion/molecule reactions were studied in a Fourier Transform Ion Cyclotron Resonance (FT-ICR) spectrometer built in this Institute and interfaced to an IonSpec Omega Fourier Transform Data System. The general characteristics of the spectrometer and its application towards the elucidation of gas-phase ion reaction sequences have been illustrated in a number of publications from these laboratories ${ }^{23-26}$. This spectrometer typically operates at a fixed magnetic field of $1.0 \mathrm{~T}$ provided by a Varian 9 inch electromagnet. The cell of the spectrometer is a modified near-cubic $15.6 \mathrm{~cm}^{3}$ oneregion cell in which center holes have been drilled on both transmitter plates to allow for laser irradiation of the ion cloud. The temperature of the cell under normal operating conditions (with the ionizing filament turned on) is typically $333 \pm 5 \mathrm{~K}$ as measured with a Pt wire thermometer located near one of the transmitter plates.

Ions were generated by pulsed electron ionization $(40 \mathrm{~ms})$ at electron energies ranging from 15 to $25 \mathrm{eV}$. Reagents were introduced in the cell through leak valves to a nominal pressure in the range of 2$6 \times 10^{-8}$ Torr as monitored by a nude ion gauge located just before the turbomolecular pump. The reactivity of ions of a given $\mathrm{m} / \mathrm{z}$ was determined by ejection of all unwanted ions from the ICR cell with a combination of short radio-frequency pulses. The kinetic behavior of the reagent ion was then investigated by obtaining mass spectra as a function of reaction time of the ions in the cell. No attempt was made to determine the absolute rate constants due to the large uncertainties associated with measuring the absolute pressure of a substrate such as $\left(\mathrm{Me}_{3} \mathrm{Si}\right)_{2} \mathrm{NH}$. Calibration experiments carried out independently for the ion gauge against an MKS Baratron micromanometer installed on one of the flanges directly opposite the cell of the spectrometer reveal that the actual pressure of HMDS inside the cell is about 2.3 times lower than that recorded on the ion gauge. This correction takes into account both the position and the relative sensitivity of the ion gauge in the spectrometer. The effect of internal energy on ion reactivity was

*e-mail: jmrnigra@iq.usp.br 
verified by comparing the kinetic behavior of primary ions isolated 50 $\mathrm{ms}$ after ion formation with that of ions thermalized by pulsing nitrogen in the cell through a General Valve type 9 pulsed valve operated with a typical aperture time of $5 \mathrm{~ms}$.

Small volumes $(<1 \mathrm{ml})$ of HMDS (Aldrich) were transferred to a glass tube under inert atmosphere, and this tube was attached directly to one of the inlets of the spectrometer. Fresh samples were used for each experiment to minimize hydrolysis of HMDS. These samples were subjected to several freeze, pump and thaw cycles prior to introduction in the cell of the spectrometer. Commercially available gases such as $\mathrm{NH}_{3}$ (Air Products), $\mathrm{C}_{2} \mathrm{H}_{5} \mathrm{NH}_{2}$ (Matheson), and $\mathrm{CH}_{3} \mathrm{NH}_{2}$ (Matheson), were used without further purification, while all other reagents were of research grade quality (Aldrich).

Since the elementary composition of some of the product ions could not be established unequivocally by their nominal $\mathrm{m} / \mathrm{z}$ relationships, mass calibration protocols were established to obtain accurate mass measurements. Spectra were typically mass calibrated by using two or three reference ions such as those obtained directly from the mass spectrum of HMDS or from the ion-molecule reactions of neat HMDS (see below). Ions used for this purpose included $\mathrm{C}_{4} \mathrm{H}_{12} \mathrm{~N}^{28} \mathrm{Si}_{2}{ }^{+}(\mathrm{m} / \mathrm{z}, 130.050829), \mathrm{C}_{5} \mathrm{H}_{16} \mathrm{~N}^{28} \mathrm{Si}_{2}{ }^{+}(\mathrm{m} / \mathrm{z}, 146.082130)$, $\mathrm{C}_{6} \mathrm{H}_{19} \mathrm{~N}^{28} \mathrm{Si}_{2}^{+}\left(\mathrm{m} / \mathrm{z}\right.$ 161.105610), $\mathrm{C}_{10} \mathrm{H}_{31} \mathrm{~N}_{2}{ }^{28} \mathrm{Si}_{4}{ }^{+}(\mathrm{m} / \mathrm{z} 291.156450)$ and $\mathrm{C}_{11} \mathrm{H}_{35} \mathrm{~N}_{2}{ }^{28} \mathrm{Si}_{4}{ }^{+}(\mathrm{m} / \mathrm{z}, 307.187740)$. Elementary composition was considered to be established when the experimental mass measurements agreed within $5 \mathrm{ppm}$. This criterion was used since the resolution $(\mathrm{m} / \Delta \mathrm{m})$ of our spectrometer at $\mathrm{m} / \mathrm{z} 150$ is probably no better than 10,000 given the magnetic field and the cell used in these experiments.

\section{RESULTS AND DISCUSSION}

A typical mass spectrum of HMDS (vertical IE measured by photoelectron spectroscopy ${ }^{27,28}$ ranges from $8.66 \mathrm{eV}$ to $8.79 \mathrm{eV}$ ) obtained in our FTICR spectrometer reveals three main processes at $25 \mathrm{eV}$ (see Figure 1 and Scheme 1).

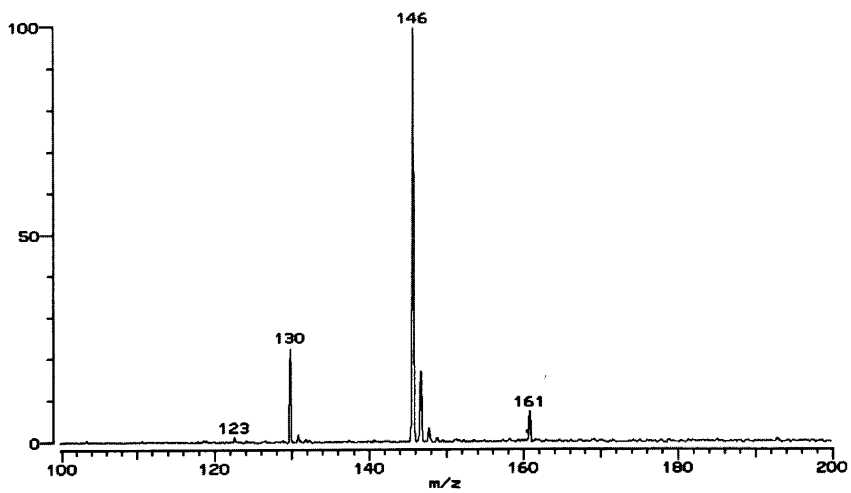

Figure 1. Mass spectrum of HMDS obtained at $25 \mathrm{eV}$ in our FT-ICR spectrometer

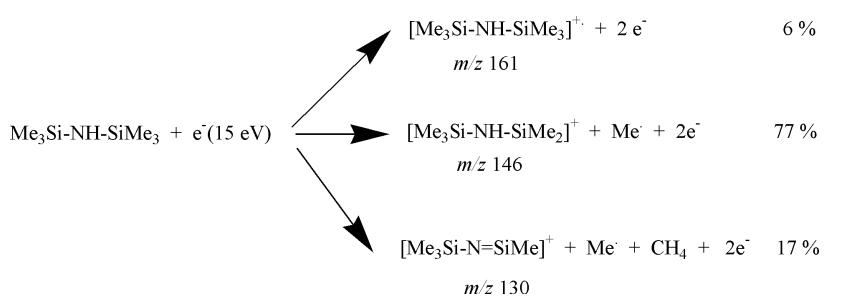

Scheme 1
At higher ionizing energies, the abundance of the $\mathrm{m} / \mathrm{z} 130$ fragment ion becomes increasingly important ${ }^{29}$. The $\mathrm{m} / \mathrm{z}$ assignment in all cases corresponds to the ions with the most abundant isotopic species.

A preliminary examination of the ensuing ion/molecule reactions of these primary ions with the parent HMDS neutral substrate reveals the molecular ion to be unreactive up to $5 \mathrm{~s}$ of reaction time. By comparison, the $m / z, 146$ and 130 fragment ions undergo slow addition reactions with the parent neutral as shown in reactions (1) and (2),

$$
\begin{aligned}
& \mathrm{Me}_{3} \mathrm{Si}-\mathrm{N}(\mathrm{H}) \stackrel{\stackrel{\oplus}{\mathrm{SiMe}}}{\mathrm{Me}_{2}}+\mathrm{Me}_{3} \mathrm{SiN}(\mathrm{H}) \mathrm{SiMe}_{3} \longrightarrow\left(\mathrm{Me}_{3} \mathrm{Si}_{2} \stackrel{\oplus}{\mathrm{N}(\mathrm{H})}-\mathrm{Si}(\mathrm{Me})_{2}-\mathrm{N}(\mathrm{H})-\mathrm{Si}(\mathrm{Me})\right. \\
& m / z 146 \\
& m / z 307 \\
& \underset{m / z 130}{\mathrm{Me}_{3} \mathrm{Si}-\mathrm{N}=\mathrm{SiMe}}+\underset{\mathrm{Me}_{3} \mathrm{SiN}(\mathrm{H}) \mathrm{SiMe}_{3}}{\longrightarrow} \underset{m / z 291}{\longrightarrow} \underset{\left(\mathrm{Me}_{3} \mathrm{Si}\right)_{2} \mathrm{~N}(\mathrm{H})-\mathrm{Si}(\mathrm{Me})=\mathrm{N}^{-}-\mathrm{SiMe}_{3}}{\longrightarrow}
\end{aligned}
$$

These reactions are typical of electrophilic silyl cations that can promote facile addition at an electron-rich center. Consequently, the structure of the product ions has been assumed to correspond to that of a protonated trisilyl amine. These product ions do not undergo further reaction with the parent neutral.

Reactions (1) and (2) were found to be very sensitive to the internal energy content of the reagent ions and reactions were observed to proceed at a reasonable rate only after the fragment ions are relaxed either by pulsing nitrogen gas, or by allowing for collisional and radiation cooling during ion trapping periods of over 1 second (Figure 2). In view of the results reported below, it is significant that neither one of the fragment ions reacts significantly with the precursor HMDS by proton transfer to yield protonated HMDS, $\left(\mathrm{Me}_{3} \mathrm{Si}\right)_{2} \mathrm{NH}_{2}^{+}(\mathrm{m} / \mathrm{z}, 162)$.

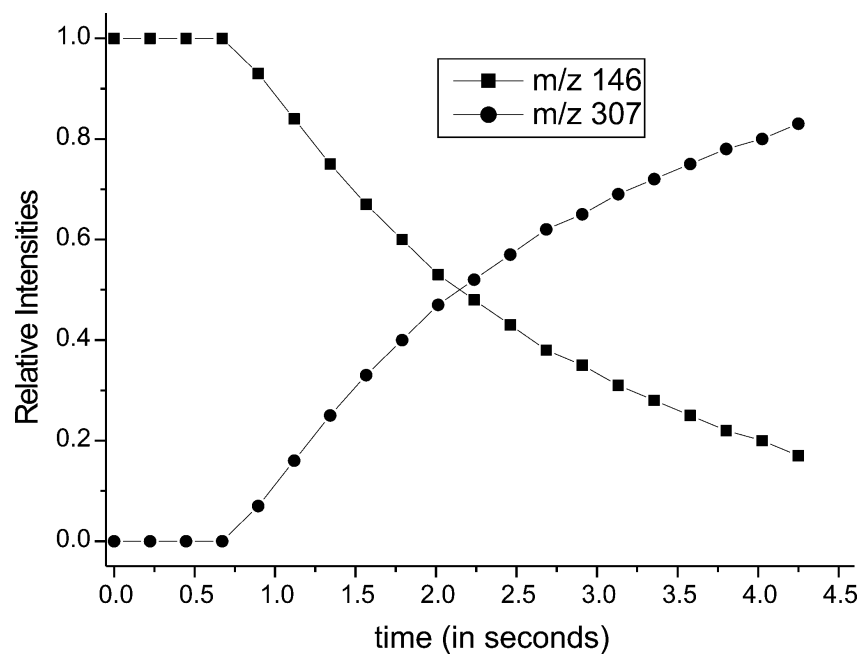

Figure 2. Normalized kinetic plot for reaction (1) with the reagent ions $(\mathrm{m} /$ $\mathrm{z}$ 146) isolated $250 \mathrm{~ms}$ after ionization. An induction time for the reaction is very noticeable and is attributed to the time necessary for the reagent ions to undergo collisional and radiation cooling

\section{Reactions of the $\mathrm{Me}_{3} \mathrm{SiN}(\mathrm{H}) \mathrm{Si}^{+}(\mathrm{Me})_{2}$ ion $\left[1^{+}\right]$}

The reactivity of the $\mathrm{Me}_{3} \mathrm{SiN}(\mathrm{H}) \mathrm{Si}^{+} \mathrm{Me}_{2}$ ion, hereafter referred to as ion $\left[\mathbf{1}^{+}\right]$, was chosen for more detailed studies in this work because of its similarity with other silyl type cations investigated in our laboratories ${ }^{17,30}$, and because they are the most abundant species in 

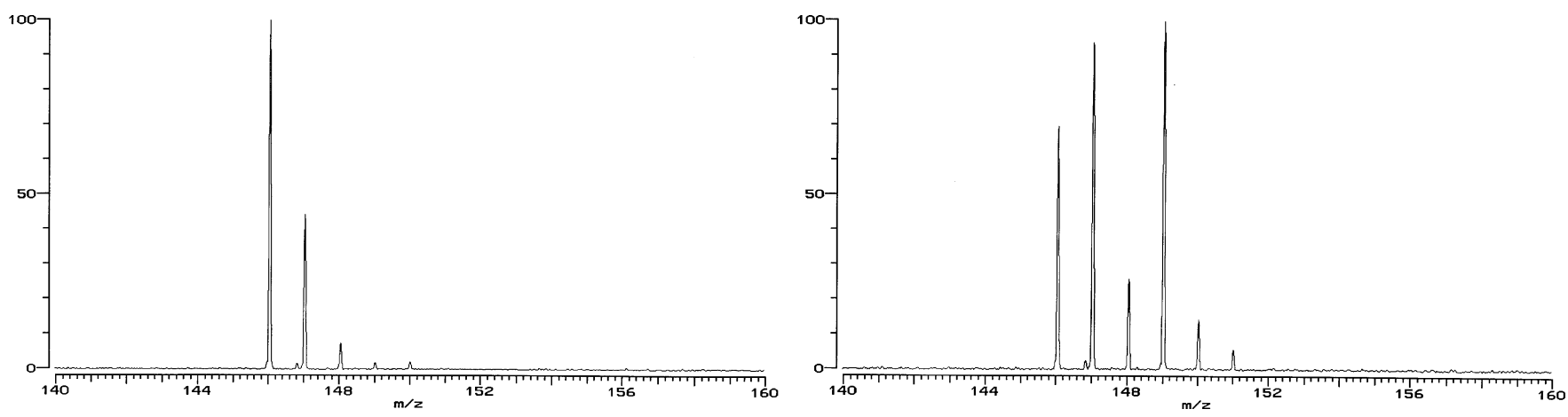

Figure 3. FT-ICR spectrum showing the reaction of the $\mathrm{m} / z 146$ ion with $\mathrm{H}_{2} \mathrm{O}$. The left side spectrum shows the ionic composition 100 ms after isolation of the $\mathrm{m} / \mathrm{z}, 146$ ion. The right side spectrum reflects the ionic composition after $500 \mathrm{~ms}$ of reaction. See reactions (3) and (4)

this system. The $\mathbf{1}^{+}$ions are assumed to retain the structure shown above by analogy with what has been determined for the corresponding $\mathrm{Me}_{3} \mathrm{SiOSi}^{+}(\mathrm{Me})_{2}$ ions obtained from hexamethyldisiloxane ${ }^{31}$.

A. Reaction with $\mathrm{H}_{2} \mathrm{O}$. Reaction of $\mathbf{1}^{+}$with water plays a major role in understanding the main features of the ion chemistry of our ion of interest. Isolated $\mathrm{m} / \mathrm{z}, 146$ ions $\left(\mathbf{1}^{+}\right.$with ${ }^{28} \mathrm{Si}$ exclusively) undergo fast reaction with neutral water to form the corresponding $\mathrm{Me}_{3} \mathrm{Si}-\mathrm{O}-$ $\mathrm{Si}^{+} \mathrm{Me}_{2}$ ions $\left(\mathrm{m} / \mathrm{z}\right.$ 147.0662, ion with both $\left.{ }^{28} \mathrm{Si}\right)$. This product ion undergoes further reaction (fast) with water as shown below and illustrated in Figure 3.

$$
\begin{aligned}
& \underset{m / z 146}{\mathrm{Me}_{3} \mathrm{Si}-\mathrm{N}(\mathrm{H})-\mathrm{Si}\left(\mathrm{Me}_{2}\right)}+\underset{\mathrm{H}_{2} \mathrm{O}}{\oplus} \longrightarrow \underset{m / z 147}{\longrightarrow} \underset{\mathrm{Me}_{3} \mathrm{Si}-\mathrm{O}-\mathrm{Si}(\mathrm{Me})_{2}}{\stackrel{\oplus}{\longrightarrow}} \longrightarrow \underset{\mathrm{NH}_{3}(3)}{\longrightarrow} \\
& \oplus \\
& \mathrm{Me}_{3} \mathrm{Si}-\mathrm{O}-\mathrm{Si}\left(\mathrm{Me}_{2}\right)+\mathrm{H}_{2} \mathrm{O} \longrightarrow \mathrm{Me}_{3} \mathrm{Si}-\mathrm{O}-\mathrm{Si}(\mathrm{Me})(\mathrm{OH})+\mathrm{CH}_{4} \\
& m / z 147 \\
& m / z 149
\end{aligned}
$$

Reaction (4) has been previously reported ${ }^{31}$ and it provides valuable confirmation that reaction (3) does indeed result in the formation of the $\mathrm{Me}_{3} \mathrm{Si}-\mathrm{O}-\mathrm{Si}^{+} \mathrm{Me}_{2}$ ion. The fact that the disappearance of the reactant ion m/z 146 is coupled with the growth of the m/z 147 ion as a function of ion trapping time is a clear indication that the $\mathrm{m} / \mathrm{z} 147$ ion results from an ion-molecule reaction and not from hydrolysis of the neutral silicon precursor. Furthermore, if hydrolysis of neutral HMDS were to occur significantly, the $m / z, 147$ ion should appear prominently in the FT-ICR spectrum obtained at short reaction times and should not exhibit the aforementioned kinetic behavior.

A more thorough analysis of the reaction products also reveals the appearance of small amounts of an ion of $\mathrm{m} / z, 148$ that eventually leads to the formation of ions with $\mathrm{m} / \mathrm{z} 150$. Accurate mass measurements are more difficult in this case because of interference from the ${ }^{29} \mathrm{Si}$ isotope of $\mathrm{m} / \mathrm{z}, 147$. However, comparison with the results obtained with the alcohols confirms that a distinct ion of $\mathrm{m} / z, 148$ ion originates from reaction (5), and this is followed by a second reaction with $\mathrm{H}_{2} \mathrm{O}$ as shown in reaction (6).

$$
\oplus
$$

\section{$\oplus$}

$$
\begin{aligned}
& \mathrm{Me}_{3} \mathrm{Si}-\mathrm{N}(\mathrm{H})-\mathrm{Si}\left(\mathrm{Me}_{2}\right)+\mathrm{H}_{2} \mathrm{O} \\
& m / z 146 \\
& \oplus \\
& \mathrm{Me}_{3} \mathrm{Si}-\mathrm{O}-\mathrm{Si}(\mathrm{Me})\left(\mathrm{NH}_{2}\right)+\mathrm{CH}_{4} \\
& m / z 148
\end{aligned}
$$

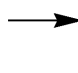

$$
\mathrm{Me}_{3} \mathrm{Si}-\mathrm{N}(\mathrm{H})-\mathrm{Si}(\mathrm{Me})(\mathrm{OH})+\mathrm{CH}_{4}
$$

The appearance of species with a ${ }^{29} \mathrm{Si}$ atom is probably due to incomplete ejection of the original reactant ion containing ${ }^{29} \mathrm{Si}$. Two possible structures are shown for the $m / z, 148$ ions because, as shown below, trimethylsilyl groups are known to migrate easily and yield rearranged ionic species.

At longer reaction times (more than 1 second), the tertiary product ions (originating from reactions 4 and 6) undergo proton transfer to neutral hexamethyldisilazane to yield protonated HMDS (main isotopic species corresponding to $\mathrm{m} / \mathrm{z}, 162$ ).

$$
\begin{aligned}
m / z .149+\mathrm{Me}_{3} \mathrm{SiN}(\mathrm{H}) \mathrm{SiMe}_{3} \rightarrow & \mathrm{Me}_{3}{ }^{28} \mathrm{Si}_{-\mathrm{N}^{+}}(\mathrm{H})_{2}{ }^{2}{ }^{28} \mathrm{SiMe}_{3} \\
& (\mathrm{~m} / \mathrm{z} 162.1134)+\text { neutral }(7)
\end{aligned}
$$

Reaction of $\mathbf{1}^{+}$with water is proposed to proceed by initial addition of the silyl cation to the water molecule even though this adduct is not observed under our experimental conditions. Yet, it is the outcome of reaction (3) that constitutes an interesting example of how the Si-N-Si system can be transformed to a Si-O-Si moiety. The behavior of this system may reflect the tendency of the HMDS skeleton to undergo metathesis reactions as previously shown by Barton and Parekh in their report on $\mathrm{Se}-\mathrm{O}$ and $\mathrm{Si}-\mathrm{N}$ bond metatheses reactions that have potential synthetic application for selective ortho amination $^{32}$. Such facile metathesis as shown in reaction (3) can be explained by a mechanism involving the formation of the adduct 1A followed by proton transfer from the oxygen to the nitrogen center to yield species 2-A in Scheme 2.

Ion 2-A can also be thought of as an ion-dipole complex involving $\mathrm{Me}_{3} \mathrm{Si}^{+}$and $\mathrm{Me}_{2} \mathrm{Si}(\mathrm{OH})\left(\mathrm{NH}_{2}\right)$. The idea that ion-dipole complexes can have an important mechanistic participation in this type of systems has been previously advanced to account for the trimethylsilyl group migration observed in mass spectral fragmentations of trimethylsilyl ethers $^{33}$, and for the outcome of ion-molecule reactions between silyl cations and ketones ${ }^{34}$. This ease of migration by methylsilyl cations is supported by preliminary ab initio calculations on model silyl systems that show such rearrangements to occur without any formal activation energy ${ }^{35}$. Scheme 2 also portrays the likely mechanism that accounts for methane elimination in reactions (4)-(6).

The fast reaction of ion $\mathbf{1}^{+}$with water is extremely important because adventitious water vapor is always present in our high vacuum system in variable amounts ${ }^{36}$. This can obscure the results obtained with other neutral substrates, particularly those that are prone to desorb water from the walls of the vacuum system.

B. Reaction with alcohols. The reaction of $\mathbf{1}^{+}$with alcohols such as methanol and ethanol follows a common pattern. In both cases, a stable addition product is observed as a minor reaction channel (see Figure 4).

$$
\begin{aligned}
& {\left[\mathrm{C}_{4} \mathrm{H}_{14} \mathrm{Si}_{2} \mathrm{NO}\right]^{\oplus}+\mathrm{H}_{2} \mathrm{O} \longrightarrow\left[\mathrm{C}_{3} \mathrm{H}_{12} \mathrm{Si}_{2} \mathrm{O}_{2} \mathrm{~N}\right]{ }^{\oplus}+\mathrm{CH}_{4}} \\
& m / z 148 \\
& m / z 150
\end{aligned}
$$




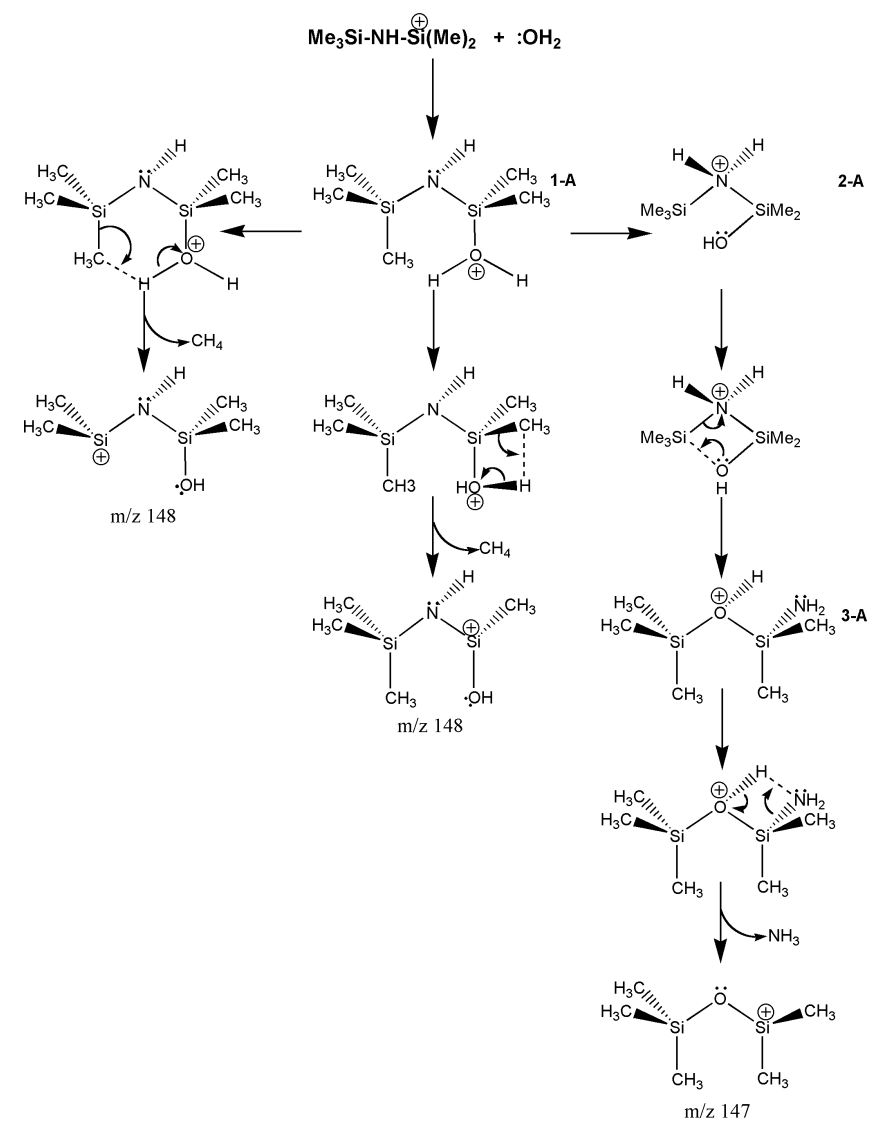

Scheme 2
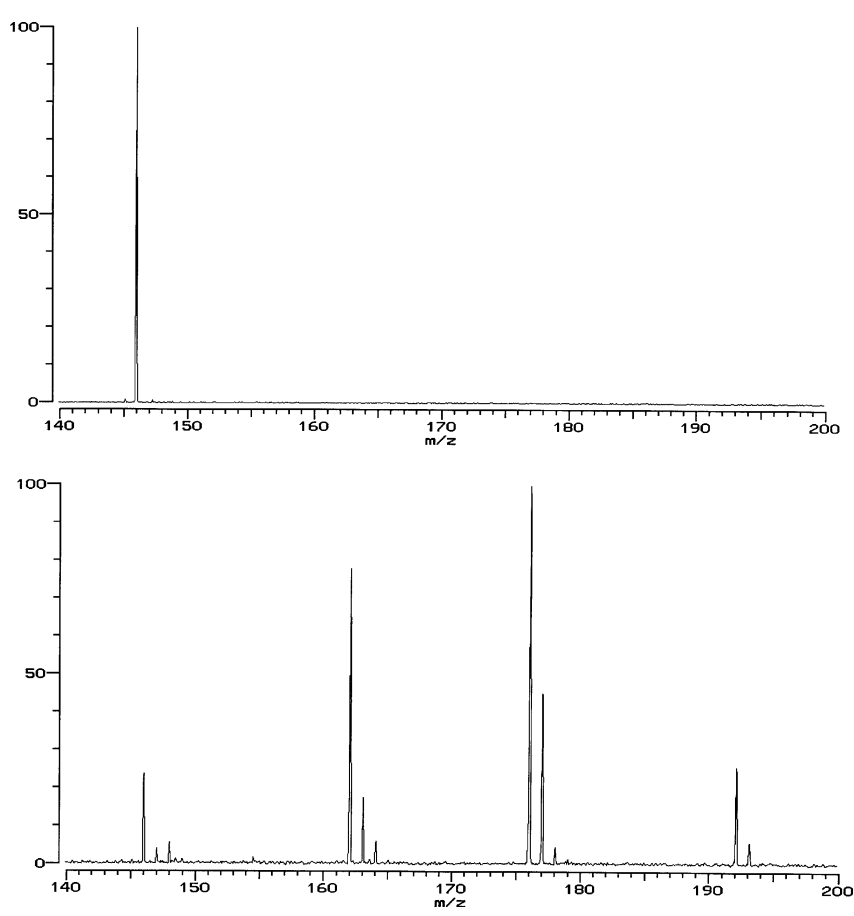

Figure 4. FT-ICR spectrum revealing the reaction of $\mathbf{1}^{+}$with ethanol. The spectrum on the top shows the ionic composition $50 \mathrm{~ms}$ after isolation of the $\mathrm{m} / \mathrm{z} 146$ ion. The spectrum on the bottom reveals the ionic composition after $2 s$ of reaction. (See reactions 9,10 and tertiary reactions leading to $\mathrm{m} / \mathrm{z}$ 177)

$$
\begin{aligned}
\mathrm{Me}_{3} \mathrm{SiN}(\mathrm{H}) \mathrm{SiMe}_{2}{ }^{+}+\mathrm{MeOH} \rightarrow & \mathrm{Me}_{3}{ }^{28} \mathrm{Si}-\mathrm{N}(\mathrm{H}){ }^{28}{ }^{28} \mathrm{Si}(\mathrm{Me})_{2}{ }^{-} \\
& \mathrm{O}^{+}(\mathrm{H})(\mathrm{Me})(\mathrm{m} / z, 178.10835) \\
\mathrm{Me}_{3} \mathrm{SiN}(\mathrm{H}) \mathrm{SiMe}_{2}{ }^{+}+\mathrm{EtOH} \rightarrow & \mathrm{Me}_{3}{ }^{28} \mathrm{Si}-\mathrm{N}(\mathrm{H}){ }^{28} \mathrm{Si}(\mathrm{Me})_{2}{ }^{-} \\
& \mathrm{O}^{+}(\mathrm{H})(\mathrm{Et})(\mathrm{m} / z \mathrm{1} 2.123999)
\end{aligned}
$$

The main reaction channels under our experimental conditions correspond to:

(1) addition of an alcohol molecule followed by elimination of methane to yield:

(a) an ion of $\mathrm{m} / \mathrm{z}, 162.07705$ for the methanol reaction, presumably $\mathrm{Me}_{3}^{28} \mathrm{Si}-\mathrm{N}(\mathrm{H}){ }^{28} \mathrm{Si}(\mathrm{Me})=\mathrm{O}^{+}-(\mathrm{Me})$, or a related isomeric species;

(b) an ion of $\mathrm{m} / \mathrm{z} 176.09270$ for the ethanol reaction, presumably $\mathrm{Me}_{3}{ }^{28} \mathrm{Si}-\mathrm{N}(\mathrm{H})-{ }^{28} \mathrm{Si}(\mathrm{Me})=\mathrm{O}^{+}$-Et, or related isomeric species;

(2) formation of an ion containing two oxygen atoms and no nitrogen atom, and identified by exact mass measurements as presumably $\mathrm{Me}_{3}{ }^{28} \mathrm{Si}-\mathrm{O}-{ }^{28} \mathrm{Si}(\mathrm{Me})=\mathrm{O}^{+}-\mathrm{Me}(\mathrm{m} / \mathrm{z}, 163.06108)$ in the methanol reaction, and $\mathrm{Me}_{3}{ }^{28} \mathrm{Si}-\mathrm{O}-{ }^{28} \mathrm{Si}(\mathrm{Me})=\mathrm{O}^{+}-(\mathrm{Et})(\mathrm{m} / \mathrm{z}, 177.07673)$ in the ethanol reaction.

The first reaction, shown in (10), follows a common pattern observed in methyl substituted silanes ${ }^{21}$ that results in methane elimination. This reaction arises from energy rich adduct ions that undergo elimination of a methyl group attached to silicon

$\mathbf{1}^{+}+\mathrm{ROH} \rightarrow\left[\mathbf{1}^{+}: \mathrm{O}(\mathrm{R})(\mathrm{H})\right]^{*} \rightarrow \mathrm{Me}_{3} \mathrm{Si}-\mathrm{N}(\mathrm{H})-\mathrm{Si}(\mathrm{Me})=\mathrm{O}^{+}-\mathrm{R}+\mathrm{CH}_{4}(10)$

However, the product ion described in (2) is remarkable and deserves further consideration in order to account for product ions with two oxygen atoms. This will be illustrated for the case of ethanol, but similar conclusions hold for the reaction with methanol.

Figure 5 shows the kinetic behavior of the different product ions starting at $0.85 \mathrm{~s}$ after isolation of ion $\mathbf{1}^{+}$. At short reaction times it is obvious that reaction (10) proceeds rapidly to yield the $\mathrm{m} / \mathrm{z}, 176$ ion and that this is the main reaction of the $\mathrm{m} / \mathrm{z} 146$ ion. However, the kinetic plot clearly indicates that the $\mathrm{m} / \mathrm{z} 176$ ion in turn undergoes further reaction with HDMS by proton transfer to yield protonated HMDS ( $m / z, 162$ and its main isotopomer at $m / z, 163)$. By comparison,

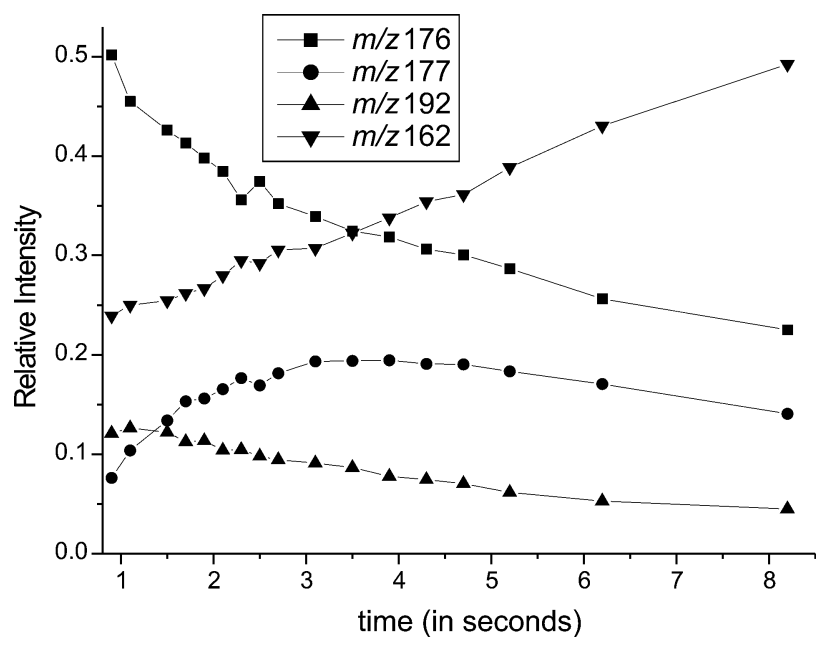

Figure 5. Kinetic behavior of the product ions in the reaction of the $1^{+}$with ethanol. This plot starts $0.85 \mathrm{~s}$ after isolation of the original reagent ion $(\mathrm{m} /$ $\mathrm{z} 146$, not shown in this graph). This graph clearly indicates that the $\mathrm{m} / \mathrm{z}$ 177 ion, presumably $\mathrm{Me} \mathrm{Si}_{3} \mathrm{O} \mathrm{O}-\mathrm{Si}(\mathrm{Me})=\mathrm{O}^{+}$-Et is a tertiary product. It is also clear that at longer times, formation of protonated HMDS (m/z 162) becomes the major product ion 
the $m / z, 177$ ion is formed much more slowly and can be clearly identified as the product of a tertiary process. Two possible routes can account for the formation of the $\mathrm{m} / z, 177$ ion: (i) reaction of the adduct ion $(\mathrm{m} / z$ 192) with a second molecule of ethanol, reaction (11)

$$
\begin{aligned}
\mathrm{Me}_{3} \mathrm{Si}-\mathrm{N}(\mathrm{H})-\mathrm{Si}(\mathrm{Me})_{2}-\mathrm{O}^{+}(\mathrm{H})(\mathrm{Et})+\mathrm{EtOH} \rightarrow \\
\mathrm{Me}_{3} \mathrm{Si}-\mathrm{O}-\mathrm{Si}^{+}(\mathrm{Me})-\mathrm{OEt}+\mathrm{EtNH}_{2}+\mathrm{CH}_{4}(11)
\end{aligned}
$$

and (ii) reaction of the $m / z, 176$ ion with ethanol (reaction 12) in a reaction similar to that of the water system.

$$
\begin{aligned}
& \mathrm{Me}_{3} \mathrm{Si}-\mathrm{N}(\mathrm{H})-\mathrm{Si}^{+}(\mathrm{Me})-\mathrm{OEt}+\mathrm{EtOH} \rightarrow \\
& \qquad \mathrm{Me}_{3} \mathrm{Si}-\mathrm{O}-\mathrm{Si}^{+}(\mathrm{Me})-\mathrm{OEt}+\mathrm{EtNH}_{2}
\end{aligned}
$$

These reactions are confirmed by experiments performed with $\mathrm{m} / \mathrm{z}, 192$ and 176 ions isolated individually although proton transfer to HMDS is the main reaction channel for these ions.

The exact mechanism for this unusual formation of the $\mathrm{m} / \mathrm{z}, 177$ and $\mathrm{m} / \mathrm{z}, 163$ ions in the reaction with ethanol and methanol respectively is not completely clear because of the competing tertiary reactions leading to protonated HMDS. Furthermore, it is unclear as to whether the $\mathrm{m} / z, 176$ and 192 ions have a unique structure or some interconversion occurs to other isomeric forms. Unfortunately, attempts to investigate the structure of these ions by collision induced dissociation (CID) proved unsuccessful in our instrument because RF ion excitation apparently leads mostly to ion ejection in our small cell. However, it is possible to speculate that the most likely mechanism is similar to that shown in Scheme 2 for reaction (3) where $\mathrm{Me}_{3} \mathrm{Si}-\mathrm{O}-\mathrm{Si}(\mathrm{Me})=\mathrm{O}^{+}-(\mathrm{Et})$, in the ethanol reaction, is a fast tertiary reaction that proceeds by elimination of neutral $\mathrm{EtNH}_{2}$.

The study of the reaction of $\mathbf{1}^{+}$with higher alcohols like 1propanol and 1-butanol proved to be more difficult because of the ease with which these alcohols release water from the walls of the vacuum system. Thus, very fast reactions were observed that are analogous to those described in reactions (3)-(6), followed by further reactions with the alcohol or HMDS. However, the main reaction of $\mathbf{1}^{+}$with these alcohols yields the $\mathrm{m} / z, 164$ ion as a result of olefin elimination from the initially formed adduct ion $\left[\mathbf{1}^{+} \cdot \mathrm{ROH}\right]$. This is exemplified in reaction for the case of propanol

$$
\begin{array}{r}
\mathbf{1}^{+}+\mathrm{C}_{3} \mathrm{H}_{7} \mathrm{OH} \rightarrow\left[\mathrm{Me}_{3} \mathrm{Si}-\mathrm{N}(\mathrm{H})-\mathrm{Si}(\mathrm{Me})_{2}^{+\cdot} \mathrm{O}(\mathrm{H})\left(\mathrm{C}_{3} \mathrm{H}_{7}\right)\right] \rightarrow \\
\mathrm{Me}_{3} \mathrm{Si}-\mathrm{O}-\mathrm{Si}(\mathrm{Me})_{2} \mathrm{NH}_{2}^{+}+\mathrm{C}_{3} \mathrm{H}_{6}
\end{array}
$$

The final product of reaction (13) has been identified again as an ion where a transposition of $\mathrm{O}$ and $\mathrm{N}$ has occurred as a result of a trimethylsilyl migration. This idea is supported by the fact that tertiary reactions in this system are consistent with this structure.
C. Reaction with other simple oxygen containing substrates. A substantially different situation occurs with neutral oxygen-containing substrates that have no labile hydrogens. For example, $\mathbf{1}^{+}$reacts with acetone exclusively by addition (see Figure 6) to yield the product shown in equation (14), where the $\mathrm{m} / \mathrm{z} 204$ ion refers to the ion with two ${ }^{28} \mathrm{Si}$.

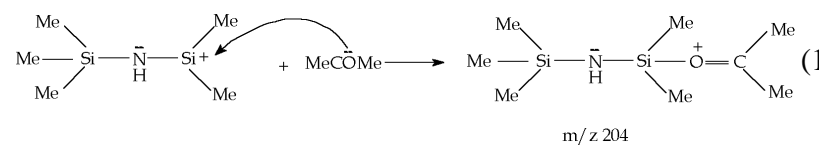

Likewise, reaction with diethyl ether (Figure 7) results primarily in addition with minor contributions from an elimination channel and tertiary reactions. The overall reactions are shown in Scheme 3.

In both of these cases, protonated HMDS $(\mathrm{m} / \mathrm{z}, 162)$ is also noticeable although not to the extent that it occurs with the alcohols.

D. Reactions with ammonia and amines. Reaction of $\mathbf{1}^{+}$with ammonia was difficult to establish because $\mathrm{NH}_{3}$ is prone to liberate

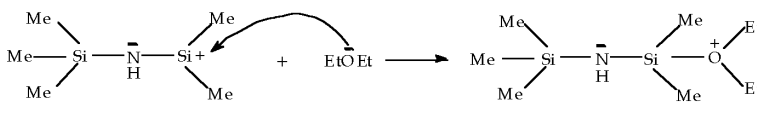

$\mathrm{m} / \mathrm{z} 220$

Addition

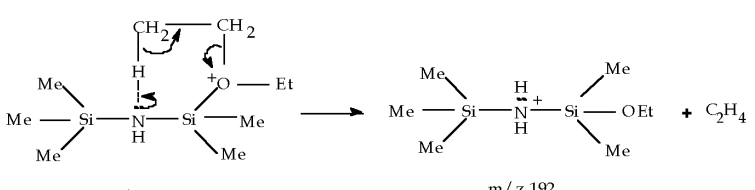

$\mathrm{m} / \mathrm{z} 220$

$$
\mathrm{m} / \mathrm{z} 192
$$

Addition-elimination

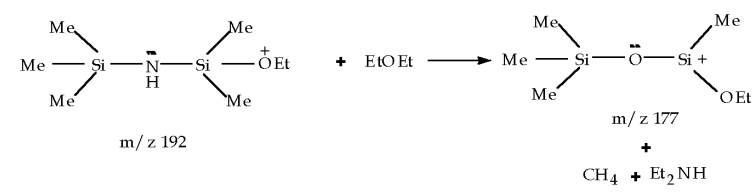

Tertiary reaction
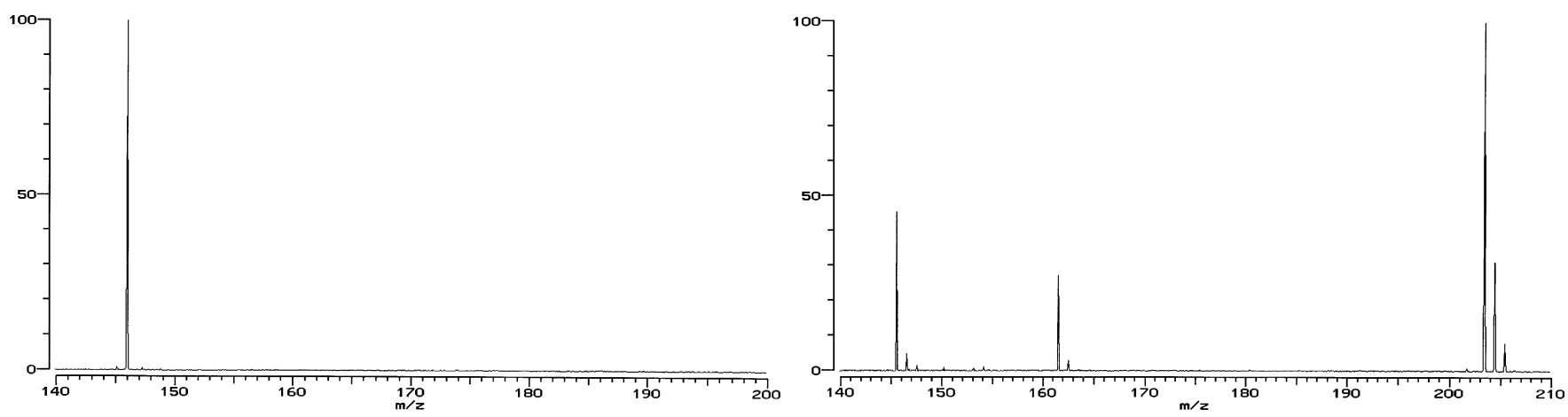

Figure 6. FT-ICR spectrum revealing the reaction of $\mathbf{1}^{+}$(shown isolated on the left hand side) with acetone. The most important reaction product is addition to yield the $\mathrm{m} / \mathrm{z} 204$ adduct ion 


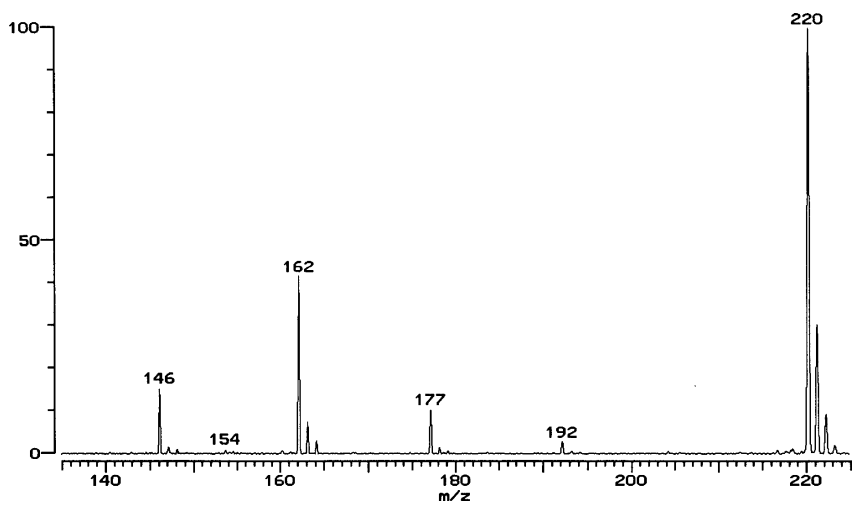

Figure 7. FT-ICR spectrum revealing the reaction of $\mathbf{1}^{+}$with diethyl ether. While the product of addition is the most important channel, the other product ions can be rationalized by Scheme 3

water from our vacuum system. As shown above, reactions with $\mathrm{H}_{2} \mathrm{O}$ are very fast and yield ions of $\mathrm{m} / z, 147$ and 149 (see reactions 3 and 4). However, after extensive seasoning of the system it was possible to conclude that $\mathbf{1}^{+}$undergoes primarily an addition reaction with $\mathrm{NH}_{3}(17 \mathrm{Da})$ to yield product ions at $m / z 163$.

The study of the reactions with $\mathrm{MeNH}_{2}$ and $\mathrm{EtNH}_{2}$ suffer similar problems because of fast reactions with adventitious water but for these cases addition is followed by elimination of either $\mathrm{CH}_{4}$ or $\mathrm{NH}_{3}$.

$\mathrm{Me}_{3} \mathrm{Si}-\mathrm{N}(\mathrm{H})-\mathrm{SiMe}_{2}^{+}+\mathrm{H}_{2} \mathrm{NR} \rightarrow \mathrm{Me}_{3} \mathrm{Si}-\mathrm{N}(\mathrm{H})-\mathrm{Si}(\mathrm{Me})_{2}-\mathrm{N}^{+}(\mathrm{H})_{2} \mathrm{R}$

$\rightarrow \mathrm{Me}_{3} \mathrm{Si}-\mathrm{N}(\mathrm{H})-\mathrm{Si}(\mathrm{Me})(\mathrm{NHR})^{+}+\mathrm{CH}_{4}$ (15b)

$$
\rightarrow \mathrm{Me}_{3} \mathrm{Si}-\mathrm{N}(\mathrm{R})-\mathrm{Si}(\mathrm{Me})_{2}^{+}+\mathrm{NH}_{3}
$$

However, the corresponding reaction from the oxygen containing ion is also very noticeable due to reaction with water.

\section{CONCLUSIONS}

The reactivity of the $\mathrm{Me}_{3} \mathrm{Si}-\mathrm{N}(\mathrm{H})-\mathrm{SiMe}_{2}{ }^{+}$cation in the gas phase can be rationalized as due to the highly electrophilic character of this species which readily undergoes addition with nitrogen and oxygen bases. Addition is followed in many cases by methane elimination when the neutral substrate has few degrees of freedom such that the addition product is not readily stabilized by radiative cooling. Yet, the most important aspect of our work is the ease with which this ion undergoes exchange of the central nitrogen by an oxygen atom with oxygen-containing bases with labile hydrogens. The mechanism for such an exchange strongly argues for the migration capabilities of trimethylsilyl groups in the addition complex formed between the original ion and the base.

\section{ACKNOWLEDGMENTS}

This work was made possible by the support of the São Paulo Science Foundation (FAPESP) and the Brazilian Research Council
(CNPq). The authors gratefully acknowledge helpful suggestions from Dr. M. L. P. da Silva who first encouraged and pioneered our gas-phase ion chemistry studies of silicon substrates relevant to microelectronics.

\section{REFERENCES}

1. Firouzabadi, H.; Karimi, B.; Synth. Commun. 1993, 23, 1633

2. Elias, A. J.; Hope, H.; Kirchmeier, R. L.; Shreeve, J. M.; Inorg. Chem. 1994, 33,415

3. Patel, N. R.; Chen, J. G.; Zhang, Y. F.; Kirchmeier, R. L.; Shreeve, J. M.; Inorg. Chem. 1994, 33, 5463.

4. Kumar, P.; Pais, G. C. G.; Keshavaraja, A.; J. Chem. Res., Synop. 1996, 376

5. Demina, M.; Velikanov, A.; Medvedeva, A.; Larina, L.; Voronkov, M.; J. Organomet. Chem. 1998, 553, 129.

6. Karimi, B.; Golshani, B.; J. Org. Chem. 2000, 65, 7228.

7. Kim, M. T.; Lee, J.; Thin Solid Films 1997, 303, 173.

8. González-Luna, R.; Rodrigo, M. T.; Jiménez, C.; Martínez-Duart, J. M.; Thin Solid Films 1998, 317, 347.

9. Pecheur, A.; Autran, J. L.; Lazarri, J. P.; Pinard, P.; J. Non-Cryst. Solids 1999, 245, 20.

10. Pereira, G. J.; da Silva, M. L. P.; Tan, I. H.; Gouvêa, D.; J. Mater. Chem. 2000, 10, 259.

11. Seekamp, J.; Niemann, J.; Bauhofer, W.; J. Non-Cryst. Solids 2000, 266, 704.

12. Haukka, S.; Root, A.; J. Phys. Chem. 1994, 98,1695.

13. Slavov, S. V.; Sanger, A. R.; Chuang, K. T.; J. Phys. Chem. B 1998, 102, 5475.

14. Slavov, S. V.; Sanger, A. R.; Chuang, K. T.; J. Phys. Chem. B 2000, 104, 983.

15. Holtgrave, J.; Riehl, K.; Abner, D.; Haaland, P. D.; Chem. Phys. Lett. 1993, 215,548 .

16. Silva, M. L. P.; Riveros, J. M.; J. Mass Spectrom. 1995, 30, 733.

17. Silva, M. L. P.; Riveros, J. M.; Int. J. Mass Spectrom. Ion Processes 1997, 165/166, 83

18. Xavier, L. A.; Riveros, J. M.; Int. J. Mass Spectrom. Ion Processes 1998, $179 / 180,223$.

19. Morgon, N. H.; Xavier, L. A.; Riveros, J. M.; Int. J. Mass Spectrom. 2000, 195/196, 363.

20. Schleyer, P. v. R.; Buzek, P.; Muller, T.; Apeloig, Y.; Siehl, H. U.; Angew. Chem., Int. Ed. 1993, 32, 1471.

21. Stone, J. A.; Mass Spectrom. Rev. 1997, 16, 35.

22. Tashiro, H.; Kikukawa, K.; Ikenaga, K.; Shimizu, N.; Mishima, M.; Perkin 2 1998, 2435.

23. Morgon, N. H.; Linnert, H. V.; Giroldo, T.; Riveros, J. M.; J. Phys. Chem. 1996, 100,18048

24. Morgon, N. H.; Argenton, A. B.; Silva, M. L. P.; Riveros, J. M.; J. Am. Chem. Soc. 1997, 119, 1708.

25. Sena, M.; Riveros, J. M.; J. Phys. Chem. 1997, 101, 4384.

26. Isolani, P.C.; Linnert, H. V.; Kida-Tinone, M. C.; Menegon, J. J.; Riveros, J. M.; Tiedemann, P. W.; Franzin, R. L.; Quim. Nova 1992, 15, 351.

27. Starzewski, K. A. O.; Dieck, H. T.; Bock, H.; J. Organomet. Chem. 1974, 65,311

28. Harris, D. H.; Lappert, M. F.; Pedley, J. B.; Sharp, G. J.; J. Chem. Soc. Dalton Trans. 1976, 945 .

29. For the typical $70 \mathrm{eV}$ mass spectrum, see NIST Standard Reference Database Number 69 - July 2001 Release at http://webbook.nist.gov/ chemistry/, acessada em Abril 2002.

30. Xavier, L. A.; unpublished results.

31. Leblanc, D.; Audier, H. E.; Denhez, J. P.; Berthomieu, D.; C. R. Acad. Sci. Paris, Ser. II, 1998, 1, 195.

32. Barton, D. H. R.; Parekh, S. I.; J. Am. Chem. Soc. 1993, 115, 948.

33. Byun, J.; Gross, M. L.; George, M.; Parees, D. M.; Kamzelski, A. Z.; Swijter, D. F. H.; Willcox, D. A.; J. Mass Spectrom. 1997, 32, 71.

34. Leblanc, D.; Audier, H. E.; Denhez, J. P.; J. Mass Spectrom. 1999, 34, 969.

35. Pliego, Jr, J. R.; personal communication.

36. It must be remembered that even though the background pressure of our instrument is typically below $4 \times 10^{-9}$ Torr, traces of water vapor are always present in spite of baking the system every night. 